\title{
Redesain dan Optimalisasi Ruang Parkir Fakultas Pertanian Kampus Bukit Jimbaran
}

\author{
MUHAMMAD RIJAL ${ }^{1}$, NANIEK KOHDRATA2*, \\ COKORDA GEDE ALIT SEMARAJAYA²
}

\author{
1Program Studi Agroekoteknologi, Fakultas Pertanian, Universitas Udayana \\ 2Program Studi Arsitektur Pertamanan, Fakultas Pertanian, Universitas Udayana \\ *E-mail: naniek_kohdrata@unud.ac.id
}

\section{ABSTRACT \\ Redesign and Optimalization of Parking Area, Faculty of Agriculture, Udayana University Bukit Jimbaran Campus}

Parking area is a facility that should be available to serve a site which has semi-public to public activities, such as a university campus. Faculty of Agriculture in Bukit Jimbaran Campus is also facing a problem to prepare a reasonably parking area for students and staffs at the vicinity. Especially within the past few years, there is a significant increase in numbers of students who use private transportation to campus. The more users and the longer class period and academic activities in campus will affect the capacity of parking spaces required in a given time. A good parking design and capacity is required to create a good atmosphere in parking habits. Some parking violations show that it has been caused by bad design. Therefore, a parking design model is proposed as a solution to the parking site in Faculty of Agriculture Udayana University, Bukit Jimbaran campus.

Keywords: parking area, parking space, parking design

\section{Pendahuluan}

\subsection{Latar Belakang}

Area parkir merupakan tempat pemberhentian kendaraan untuk waktu sementara atau digunakan untuk menaruh kendaraan pribadi pada suatu kegiatan. Ketersediaan lahan parkir merupakan fasilitas yang harus tersedia secara layak pada tempat kegiatan penggunanya (Setiawan, 2008). Jumlah mahasiswa di Fakultas Pertanian Universitas Udayana (FP Unud) mengalami peningkatan dalam beberapa tahun terakhir dan juga mengindikasikan jumlah peningkatan pengguna moda transportasi pribadi. Indikasi tersebut dapat sejalan dengan kebijakan mengenai masa perkuliahan bagi mahasiswa FP semester 1-8 yang wajib dilaksanakan di kampus FP Bukit Jimbaran (Rapim FP, 2014). Kontribusi jumlah mahasiswa yang beraktivitas di kampus FP Unud juga berasal dari mahasiswa prodi IImu Komputer (IIkom) FMIPA Unud semester I-VIII yang menggunakan beberapa gedung milik FP Unud. 
Korelasi antara jumlah pengguna dari mahasiswa atau staf FP Unud dan prodi Iklom FMIPA Unud relatif akan berbanding lurus dengan jumlah kendaraan yang digunakan. Semakin banyak jumlah pengguna dan semakin lama masa studi mahasiswa maka akan mempengaruhi kapasitas ruang parkir yang diperlukan dalam satuan waktu tertentu.

Upaya penataan ulang tata letak parkir di FP Unud dapat menjadi solusi untuk mengurai beberapa masalah yang ada guna memaksimalkan fungsi dari luasan area parkir yang telah disediakan. Perubahan serta pengkajian lebih lanjut dari segi tata letak area parkir FP Unud perlu dilakukan untuk menunjang pemanfaatan area parkir yang maksimal dan efisien. Fungsi dari area parkir yang telah ada dapat dipertimbangkan kembali untuk dilakukan pembenahan sebagai upaya nyata dalam memenuhi fasilitas umum yang vital di lingkungan FP Unud kampus Bukit Jimbaran. Rumusan masalah dari penelitian ini terdiri dari 1) perilaku pengguna di area parkir FP Unud kampus Bukit Jimbaran, 2)model desain area parkir yang efektif digunakan untuk mengatasi permasalahan penggunaan area parkir saat ini. Sedangkan beberapa tujuan yang ingin dicapai dalam penelitian ini adalah 1) untuk mengetahui perilaku pengguna kendaraan pribadi dalam memanfaatkan area parkir yang disediakan di FP Unud kampus Bukit Jimbaran pada saat penelitian berlangsung. 2) memperbaiki penataan area parkir di FP Unud agar didapatkan desain yang efektif guna mendorong perilaku tertib pengguna.

\section{Metode Penelitian}

\subsection{Waktu dan Tempat Penelitian}

Penelitian direncanakan selama enam bulan. Pengambilan data terkait jumlah kendaraan yang parkir berlangsung dari tanggal 14 Maret - 18 April 2016. Area penelitian berletak di area parkir FP Unud kampus Bukit Jimbaran. Luas area penelitian yang digunakan adalah 2804,25 $\mathrm{m}^{2}$. Terdiri dari area parkir sepeda motor (sepeda motor) seluas $2.100 \mathrm{~m}^{2}$ dan area parkir mobil 704,25 $\mathrm{m}^{2}$.

\subsection{Alat Penelitian}

Alat dalam penelitian ini adalah sarana yang digunakan untuk mengumpulkan data pada obyek penelitian. Alat yang digunakan dalam penelitian adalah : kuisioner, denah FP Unud, meteran rol $30 \mathrm{~m}$, alat tulis, kalkulator, kamera digital.

\subsection{Metode}

\subsubsection{Metode Desain}

Metode yang digunakan dalam melakukan pemodelan desain ruang parkir adalah penerapan standar satuan ruang parkir (SRP). Luas standar SRP dapat dilihat sebagai berikut:

Tabel 2.1 Dimensi Satuan Ruang Parkir (SRP)

\begin{tabular}{clc}
\hline No. & \multicolumn{1}{c}{ Jenis Kendaraan } & Satuan Ruang Parkir $\left(\mathrm{m}^{2}\right)$ \\
\hline 1 & Mobil penumpang untuk golongan I & $2,30 \times 5,00$ \\
\hline 2 & Sepeda Motor & $0,70 \times 2,00$
\end{tabular}

Sumber: Direktorat Jendral Perhubungan Darat (2011)

\subsubsection{Metode Pengambilan Data}


Metode yang digunakan adalah metode studi pustaka, observasi lapangan dan wawancara kepada penyelenggara dan pengguna. Proportionate Stratified Random Sampling adalah pengambilan sampel yang dilakukan berdasarkan pembagian dan proporsional. Pembagian dilakukan berdasarkan pada pembagian kelas pengguna seperti yang tercantum dalam tabel berikut :

Tabel 2.2 Pembagian Kategori Responden

\begin{tabular}{clcc}
\hline No. & Kategori Pengguna & Total & Sampel \\
\hline 1 & Dosen & 57 & 5 \\
2 & Mahasiswa FP Unud & 443 & 90 \\
3 & Mahasiswa llkom FMIPA Unud & 230 & 34 \\
\hline \multicolumn{2}{c}{ Total } & 730 & $129(17,67 \%)$ \\
\hline
\end{tabular}

Sumber : Biro Akademik FP Unud dan Prodi Ilkom FMIPA Unud (2016)

\section{Hasil dan Pembahasan}

Survey jumlah kendaraan parkir dilakukan dengan cara menghitung jumlah kengendaraan yang keluar dan masuk setiap jamnya. Digunakan asumsi bahwa aktivitas dosen, pegawai dan mahasiswa di lingkungan FP Unud dimulai dari pukul 07.00 WITA dan berakhir pada pukul 16.00 WITA. Pengamatan dilakukan selama satu bulan masa kuliah efektif terhitung sejak tanggal 14 Maret sampai dengan tanggal 18 April 2016.

\subsection{Jumlah Kendaraan Pengguna Area Parkir}

Jumlah pengguna kendaraan pribadi dihitung dari jumlah rata-rata berdasarkan hari efektif (Senin-Jumat) selama penelitian. Jumlah terbanyak yang tercatat selama penelitian akan dijadikan acuan dalam pelaksanaan redesain. Selama penelitian berlangsung di FP Unud, jumlah sepeda motor tercatat terbanyak adalah 162 sepeda motor dan mobil sebanyak 12 mobil.

\subsection{Perilaku Pengguna}

Perilaku pengguna secara umum yang akan dijadikan acuan dalam hal ini adalah menggolongkan pengguna secara garis besar terlebih dahulu. Pengelompokan dibagi menjadi tiga bagian, yaitu pengguna dari kalangan dosen dan pegawai, mahasiswa FP Unud dan mahasiswa prodi llkom FMIPA Unud. Pembagian tersebut bertujuan untuk mengetahui perilaku pengguna, jenis pelanggaran dan masalah yang terjadi, sehingga dapat diketahui jenis ketidak patuhan pengguna di area parkir. 


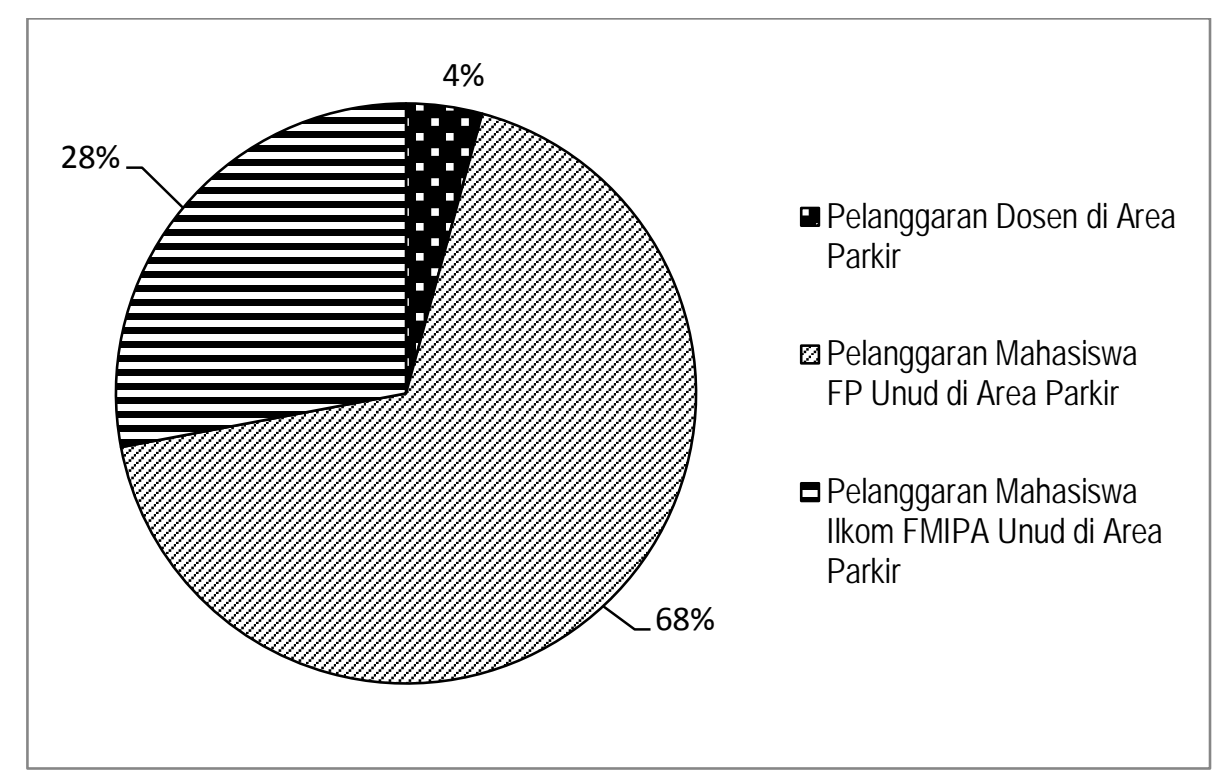

\section{Gambar 3.1 Pelanggaran Responden}

Pembuktian yang tertera pada diagram pelanggaran, maka dapat dilihat jika pengguna melakukan pelanggaran. Golongan mahasiswa FP Unud yang sebanyak 68\%. Mahasiswa Ilkom FMIPA Unud sebanyak 28\%. Pelanngaran lain dilakukan oleh dosen sebanyak 4\% (Gambar 3.1).

Perilaku melanggar tersebut tentu menunjukkan ada sesuatu yang salah diperkirakan terdapat pada area parkir hususnya area parkir sepeda motor. Penyebabnya dapat diindikasikan dari dua faktor yang mempengaruhi perilaku pengguna, yaitu antara faktor karakter dari mahasiswa yang pada dasarnya tidak taat dan faktor dari desain yang mendorong pengguna untuk melakukan pelanggaran.

Perilaku pengguna yang telah digolongkan masing-masing berada pada lingkungan yang homogen. Lingkungan homogen mempunyai kecenderungan bagi penggunanya untuk meniru contoh yang ada terlebih dahulu atau telah terbiasa terjadi. Alasan pelanggaran tersebut terjadi dikarenakan ada yang memulai, sehingga banyak pengguna lain mengikuti pelanggar sebelumnya, tidak adanya kelengkapan penunjang parkir yang disediakan oleh pengelola, dan beberapa alasan pada Gambar 3.2.

Alasan pengguna yaitu dari mahasiswa FP Unud dan Ilkom FMIPA Unud yang mengikuti pelanggar yang lebih dahulu datang menjadi alasan yang terbanyak. Alasan mengikuti pelanggar sebelumnya menyumbang 41 responden (35\%) dan mahasiswa Ilkom FMIPA Unud sebanyak 17 responden (14\%) dan total alasan ini adalah 49\% (Gambar 3.2) Indikasi yang muncul adalah pelanggar yang lebih dahulu datang dapat mempengaruhi pengguna selanjutnya untuk mengikuti perilaku melanggar. 


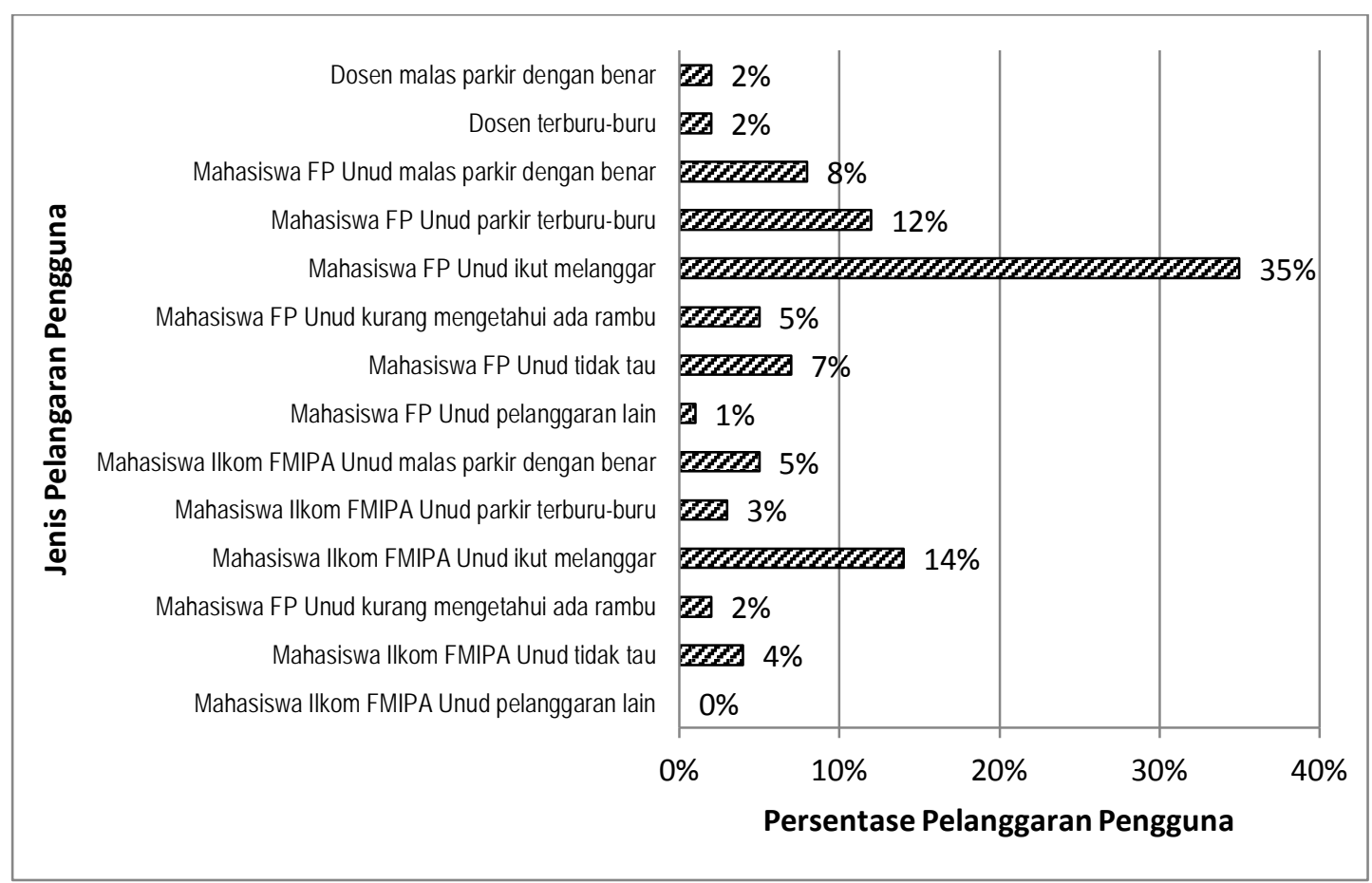

\section{Gambar 3.2 Alasan Pelanggaran Responden}

Alasan pelanggaran yang disebabkan karena mengikuti kendaraan yang lebih dahulu datang atau lebih dahulu melanggar menempati persentase tertinggi yaitu sebesar $48 \%$. Penyebab jenis pelanggaran lain adalah perilaku meniru seperti pengguna sebelumnya dan secara tidak langsung dianggap sebagai contoh. Responden selanjutnya adalah responden yang memilih pelanggaran parkir di depan gedung Dekanat FP Unud (12\%) dan parkir asal-asalan di area yang disediakan (36\%) (Gambar 3.2). Penelitian didukung dengan temuan Aditya (2014), alasan pengguna asal-asalan memarkir kendaraan pribadi akan digunakan ketika pengguna mengalami beberapa keadaan dan di antaranya : keperluan pengendara yang mendesak, terlambat, kebutuhan waktu parkir yang singkat, pengendara sulit/ tidak menemukan parkir, tanda rambu parkir tidak terlihat, adanya petugas parkir yang memarkirkan di daerah bukan perntukan parkir, aspek meniru serta kebiasaan. Perilaku tidak sekedar muncul berdasarkan pengalaman masa lampau, tetapi juga secara terus menerus berubah atau diubah oleh lingkungan. Gambaran mengenai pelanggaran yang dilakukan pengguna di area FP Unud dapat dilihat pada Gambar 3.3.

Urgensi dalam penataan area parkir adalah kebutuhan dan hasil survei responden menunjukkan menunjukkan keinginan responden mengenai perubahan area parkir. Perubahan yang dimaksud dalam penelitian sebatas penataan ruang parkir. Tata letak parkir dapat dibentuk berdasarkan perilaku pengguna yang sudah terdata untuk mendorong perilaku yang positif.

Mayoritas responden sepakat bahwa perubahan tata letak area parkir diperlukan. Responden yang menunjukkan tidak setuju untuk dilakukan perubahan sebesar 36\% responden atau kurang dari setengah jumlah keseluruhan responden (Gambar 3.4) 

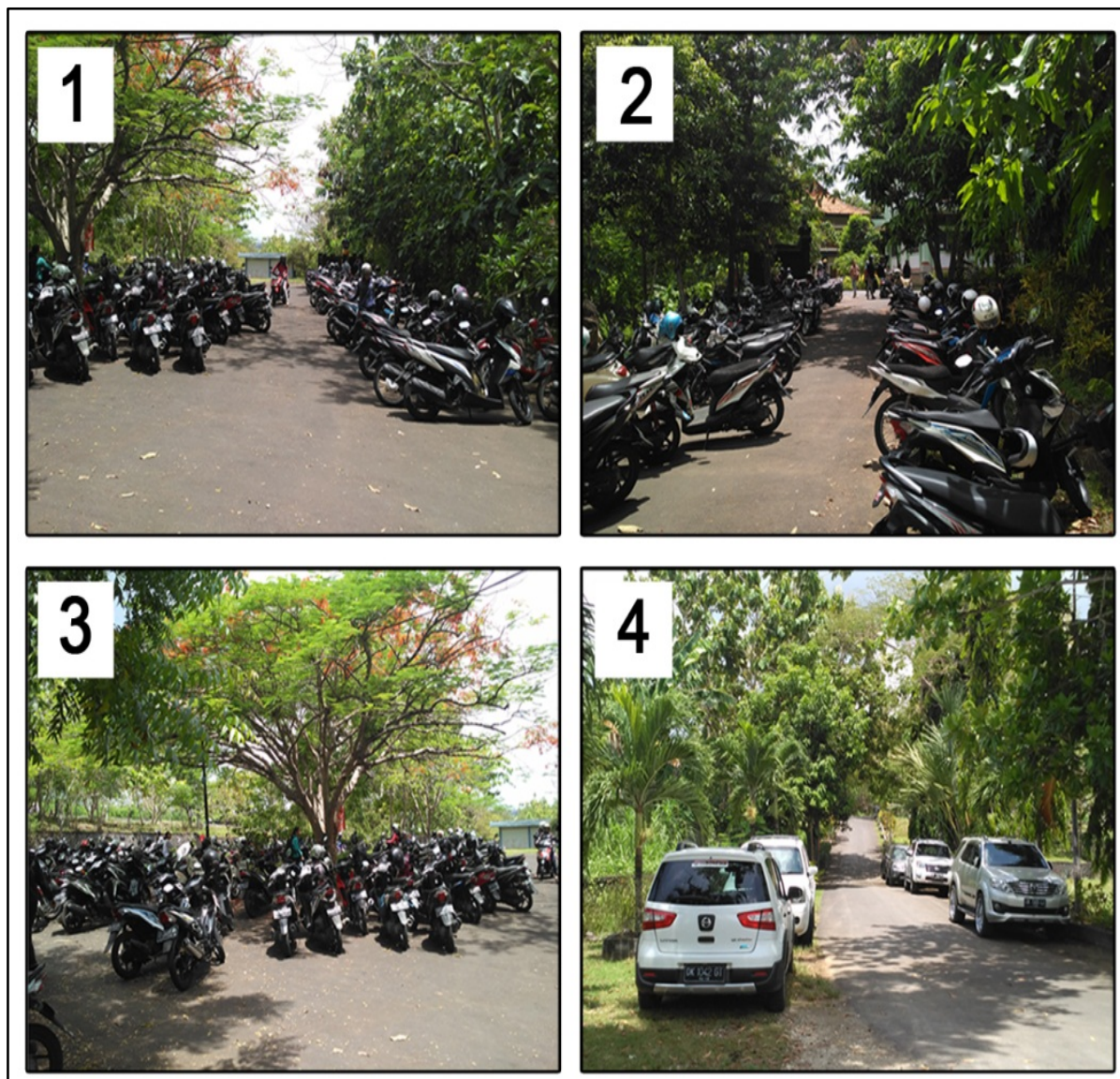

Keterangan :

1. Sirkulasi di dalam area parkir sepeda motor FP Unud.

2. Pelanggaran pengguna yang dilakukan di sirkulasi utama menuju area parkir FP Unud.

3. Pengguna yang parkir sembarangan di area parkir sepeda motor FP Unud.

4. Pengguna mobil yang memarkirkan kendaraan di jalan masuk utama menuju FP Unud.

Gambar 3.3 Contoh Pelanggaran Parkir yang Dilakukan di FP Unud

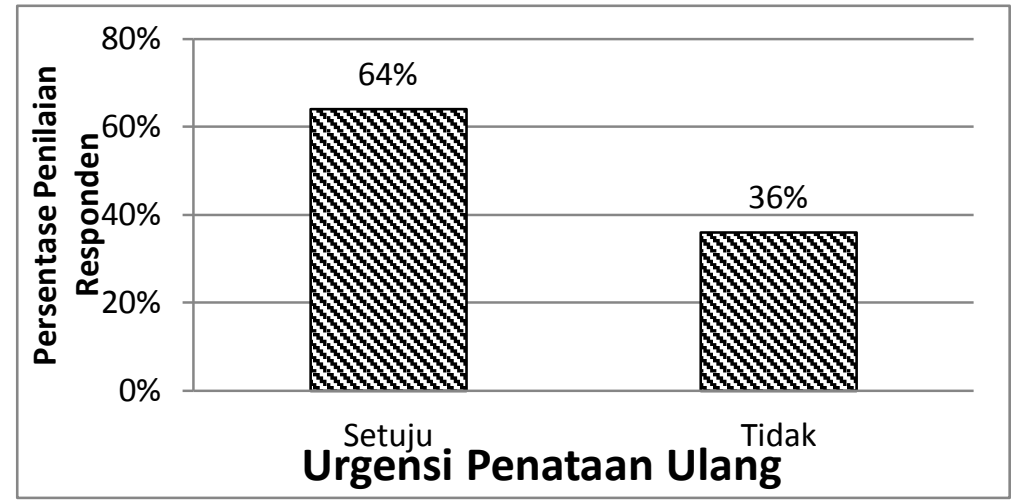

Gambar 3.4 Urgensi Penataan Ulang Area Parkir 


\subsection{Desain Area Parkir}

Desain area parkir direncanakan dengan menggunakan dua pendekatan, yaitu aspek efisiensi dan aspek optimalisasi. Aspek efisiensi adalah pemanfaatan area parkir untuk menampung sebanyak mungkin sepeda motor. Aspek optimalisasi adalah pendekatan yang mengedepankan desain yang mampu mencakup segala kebutuhan pengguna area parkir berdasarkan perilaku pengguna.

Perencanaan tata letak area parkir di FP Unud merupakan proses utama dalam mengkorelasikan data pada ulasan sebelumnya yaitu data jumlah kendaraan dan data perilaku pengguna area parkir untuk dipertemukan pada sebuah titik solusi berupa desain tata letak. Standar yang digunakan dalam penelitian ini adalah pedoman pelaksanaan parkir oleh Direktorat Jendral Perhubungan Darat Dinas Perhubungan (2011)

\subsubsection{Perhitungan dan Permodelan Area Parkir Sepeda Motor}

Desain juga mengedepankan sisi efisiensi pemanfaatan area yaitu menampung sebanyak mungkin sepeda motor yang dapat ditampung dan telah disesuaikan dengan beberapa standar. Desain efisien ditujukan untuk jumlah SRP yang banyak dan dapat mengakomodir kebutuhan parkir yang jauh lebih besar untuk antisipasi beberapa kegiatan dan kebijakan seperti pemindahan seluruh kegiatan di kampus FP Unud. Desain efisien mampu menampung sebanyak 502 sepeda motor dengan menggunakan sudut parkir $90^{\circ}$.

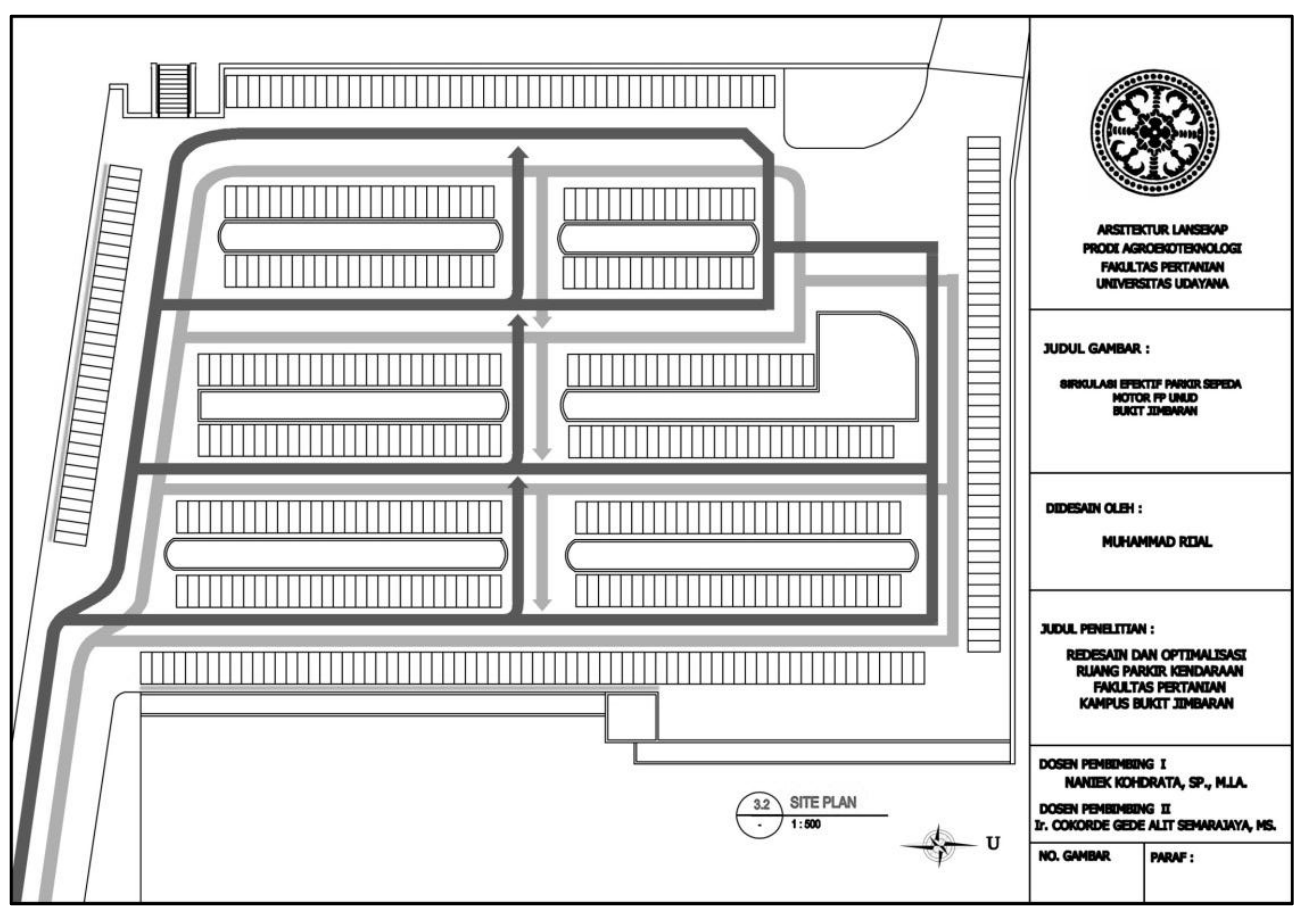

Gambar 3.5 Desain Area Parkir Sepeda motor Efisien

Desain area parkir sepeda motor optimum ditujukan untuk mengakomodir sebanyak mungkin kebutuhan pengguna seperti kenyamanan, kemudahan dan alur sirkulasi bagi 
pengguna. Desain area parkir sepeda motor optimum mampu menampung 469 sepeda motor dengan sudut kemiringan SRP $60^{\circ}$.

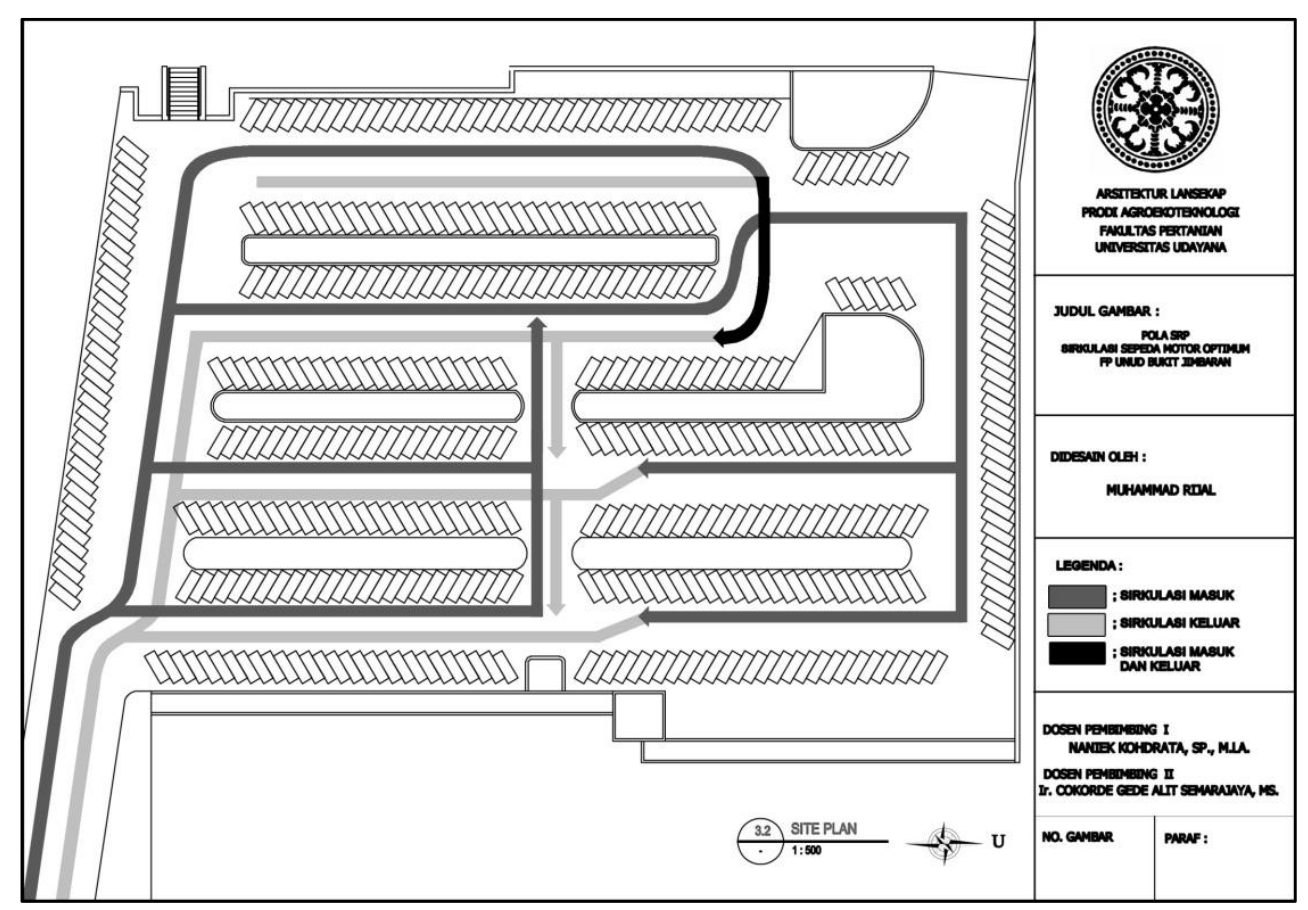

Gambar 3.6 Desain Area Parkir Sepeda motor Optimum

Analisa perhitungan dan permodelan area parkir menunjukkan bahwa untuk kondisi saat penelitian, maka perimbangan yang dipakai sebagai dasar memilih model optimum adalah desain yang dianggap dapat mengakomodir keadaan saat ini dan beberapa waktu mendatang adalah desain parkir sepeda motor optimum. Perilaku pengguna yang malas memarkirkan sepeda motor dengan benar dapat diatasi dengan menerapkan pola desain dengan sudut sebesar $60^{\circ}$, yaitu sudut yang searah dengan jalan masuk sehingga pengguna yang malas memarkir dapat langsung menaruh kendaraan dengan posisi yang mendukung. Pilihan desain optimum tentu tidak lepas dari evaluasi parkir yang terjadi selama ini, yaitu parkir sebelumnya yang secara normatif menerapkan sudut pola $90^{\circ}$ dan dengan itu pengguna cenderung parkir sembarangan.

Desain terpilih adalah desain yang dinilai mempunyai kapasitas baik kapasitas fisik berupa daya tampung yang banyak, kondisi fisik yang baik. Ada pula pertimbangan lain yaitu perilaku pengguna berkaitan dengan kenyamanan, keamanan dan kemudahan bagi pengguna. Dengan rentang waktu yang parkir yang lama dan didukung dengan perilaku pengguna, maka yang terjadi adalah pengguna akan melakukan parkir secara asal-asalan. Terbukti sebanyak 73\% responden mengakui kebiasaan melakukan parkir asal-asalan pada area yang sudah disediakan.

\subsubsection{Desain Area Parkir Mobil}

Parkir mobil yang dimiliki oleh FP Unud berada di sisi selatan dan barat gedung dekanat dengan luas $704,25 \mathrm{~m}^{2}$. Mempunyai dua bentuk dasar berupa persegi dan persegi 
panjang mengerucut pada bagian barat belakang. Desain area parkir mobil mempunyai kapasitas yang mampu menampung 39 mobil dengan derajat sudut pola yang diterapkan sebesar $90^{\circ}$. Derajat pola tersebut dipilih karena area parkir mobil hanya mempunyai satu jalur sirkulasi dengan lebar antara 4-5,85 meter. Ruang yang tersisa masih cukup untuk melakukan manuver saat mobil masuk atau keluar.

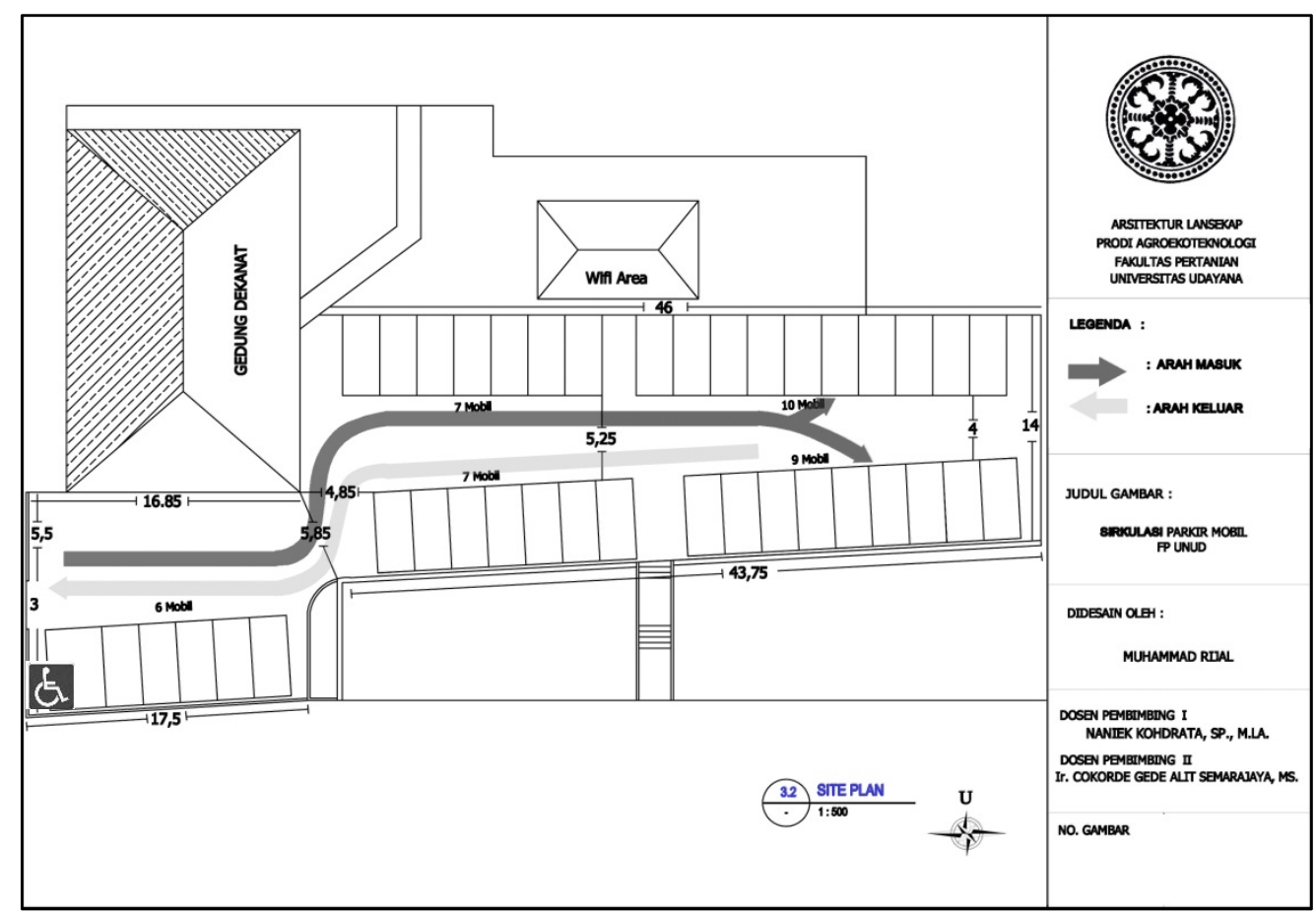

Gambar 3.7 Desain Area Parkir Mobil

\section{Simpulan}

\subsection{Perilaku Pengguna}

Perilaku pengguna sepeda motor dinilai dari ketertiban selama melakukan parkir. Selama penelitian terekam banyak jenis pelanggaran seperti parkir asal-asalan di area yang telah disediakan, parkir di depan gedung Dekanat FP Unud atau parkir di dekat gedung BI. Pelanggaran tertinggi adalah pengguna sepeda motor yang parkir asal-asalan (74\%). Perilaku parkir asal-asalan dapat diperbaiki dengan menerapkan pola SRP di area parkir.

Perilaku pengguna mobil selama penelitian dinilai tertib atau sedikit terjadi pelanggaran. Jumlah pengguna mobil seluruhnya adalah dari kategori dosen. Perilaku tersebut disebabkan jumlah mobil yang parkir sedikit dan ruang yang tersedia cukup untuk parkir mobil selama penelitian.

\subsection{Model Desain}

Area parkir sepeda motor mempunyai luas $2.100 \mathrm{~m}^{2}$. Jumlah sepeda motor yang parkir di dalamnya angka tertinggi yang dicapai adalah 162 sepeda motor. Dimensi SRP yang digunakan seluas $2 \mathrm{~m} \times 0,7 \mathrm{~m}$. Desain area parkir sepeda motor yang digunakan adalah model area parkir sepeda motor optimum. 
Area parkir mobil mempunyai luas $704.25 \mathrm{~m}^{2}$. Jumlah pengguna tertinggi yang tercatat adalah sebanyak 12 mobil. Pola yang diterapkan pada tata letak desain parkir mobil menggunakan kemiringan $90^{\circ}$. Dengan pola tersebut maka dari area yang tersedia dapat dimaksimalkan untuk 39 SRP mobil dan dan salah satunya diperuntukkan penyandang disabilitas.

\section{Daftar Pustaka}

Aditya G, R. 2014. Kampanye Pencegahan Parkir Kendaraan Bermotor pada Tempat yang Tidak Tepat di Kota Bandung. 17(9) Fakultas Seni Rupa dan Desain Institut Teknologi Bandung. Bandung

Direktorat Jendral Perhubungan Darat, Dinas Perhubungan. 2011. Pedoman Teknis Penyelenggaraan Fasilitas Parkir. Dinas Perhubungan. Jakarta

Rapim FP Unud. Agustus 2014. Fakultas Pertanian Universitas Udayana. Badung

Setiawan. 2008. Dampak Perubahan Dimensi Ruang Parkir Terhadap Waktu Manuver Parkir. Universitas Kristen Petra. Surabaya 